\title{
STATUTORY REGULATION OF HOUSEBREAKING AND INTRUSION IN SOUTH AFRICA - AN HISTORICAL PERSPECTIVE
}

\section{Shannon Hoctor*}

\section{ABSTRACT}

This article discusses the statutory offences which regulated the unlawful conduct of housebreaking and intrusion in association with the common-law crime of housebreaking, taking account of antecedent and analogous provisions in the English law, as well as the developments in respect of these offences, prior to their repeal. The utility of these offences is thus considered, prior to an assessment of the reasons for their repeal.

Keywords: Housebreaking offences; housebreaking implements; breaking; entering; dwelling; premises; night; lawful excuse

\section{Introduction}

Prior to the inception of the Union of South Africa in 1910, each of the four provincial legislatures had enacted statutory forms of the crime of housebreaking. These were not intended to override the common-law version of the crime, but rather to supplement it. In so doing these offences provided an alternative basis of criminal

* Professor, School of Law, University of KwaZulu-Natal. 
liability in terms of the prohibited conduct which overlapped with the ambit of the common-law crime, as well as extending the scope of the prohibited conduct as such, by, for example, criminalising the possession of housebreaking implements. Aspects of these provincial offences remained in force until 1993, when in terms of section 82 of the General Law Third Amendment Act ${ }^{1}$ the new statutory offence of "failure to give a satisfactory account of the possession of an implement or object" was created. This offence replaces the provincial housebreaking offences relating to possession of housebreaking implements, creating a uniform national crime in this regard. The creation of a single national crime of trespass ${ }^{2}$ also played a role in the gradual phasing out of aspects of these offences. However, these offences, founded on pre-Union legislation, have played a significant part in the control of this area of criminal activity for over a hundred years, and will be examined below.

First, it should be noted that, in accordance with the uncertain status of the common-law housebreaking crime in Roman-Dutch law, ${ }^{3}$ these statutory offences have English law antecedents. ${ }^{4}$ The relevant English legislation directly preceding the pre-Union statutes was the Larceny Act $1861 .{ }^{5}$ Section 58 of this statute provided as follows:

1 General Law Third Amendment Act 129 of 1993. Section 82 provides as follows: “Any person who possesses any implement or object in respect of which there is a reasonable suspicion that it was used or is intended to be used to commit housebreaking, or to break open a motor-vehicle or to gain unlawful entry into a motor-vehicle, and who is unable to give a satisfactory account of such possession, shall be guilty of an offence." On this offence, see Hoctor 1999b: 225-239. In terms of s 84 of this Act, the following laws were repealed: the unrepealed provisions of the Police Offences Act 27 of 1882 (C); the Native Territories Penal Code (Act 24 of 1886 (C)); s 6(2)(c) of the Criminal Law Amendment Act of $1910(\mathrm{~N})$; s 26(1) of the Police Offences Ordinance 21 of 1902 (O); and s 7(b) of the Crimes Ordinance 26 of 1904 (T).

2 In terms of $\mathrm{s} 1$ of the Trespass Act 6 of 1959.

3 Whilst the prevailing wisdom among South African writers is that in Roman-Dutch law housebreaking with intent to steal and theft was treated as an aggravated form of theft, and that the offence as such was unknown in Roman-Dutch law (Milton 1996: 794; Snyman 2014: 543; Pittman 1950: 158; Gie 1941: 96; Anders \& Ellson 1915: 142; De Wet 1985: 362; Burchell 2016: 767); the authorities appear to be somewhat contradictory. Voet (see Gane 1955) in one passage merely treats housebreaking as aggravated theft (47 29$)$, and in another (47 18 1) as a substantive offence (as pointed out by the court in $R v$ Fourie/Louw 1907 ORC 58 and $S v$ Maunatlala 1982 (1) SA 877 (T)). Similarly, Matthaeus (see Hewett \& Stoop 1987) seems to regard housebreaking as aggravated theft at one point in his treatise (47 $139 \& 471312)$ and as a substantive offence at another (47 21 1) (see $R v$ Thompson 1905 ORC 27; S v Jecha 1984 (1) SA 215 (Z)). Gardiner JP in $R$ v Mososa 1931 CPD 348 states that housebreaking was indeed a substantive offence in Roman-Dutch law, citing Carpzovius, Boehmer, Leyser, Barel, Voet and Menochius in support of this position. On the other hand, authorities such as Van Leeuwen 1720: 4383 and Van der Linden 1806: 262 state that housebreaking constitutes aggravated theft.

4 On the history of the housebreaking crime, see Hoctor 1999a: 97-103.

$524 \& 25$ Vict Cap 96. 
Whosoever shall be found by night armed with any dangerous and offensive weapon, or instrument whatsoever, with intent to break and enter into any dwelling-house or other building whatsoever, and to commit any felony therein, or shall be found by night having in his possession without lawful excuse (the proof of which excuse shall lie on such person) any picklock key, crow, jack, bit, or other implement of housebreaking, or shall be found by night having his face blackened or otherwise disguised with intent to commit any felony, or shall be found by night in any dwelling-house or other building whatsoever, with intent to commit any felony therein, shall be guilty of a misdemeanour ...

It is evident that this omnibus provision essentially contains inchoate or anticipatory offences, with the common denominator that the accused must "be found by night", allowing the police to arrest the accused on the basis of such indicators of nefarious intent as possession of a weapon, or possession of an implement used for breaking into a premises, or being in disguise, or being present in a premises with intent to commit a felony therein. Such offences thus serve as a means to punish an actor before the envisaged harm has been completed. ${ }^{6}$ The Larceny Act of 1861 was repealed and replaced by the Larceny Act 1916, although the offences contained in the 1861 Act were essentially repeated in section 28 of the new legislation. ${ }^{7}$ As will be evident from the discussion that follows, these provisions were influential in the framing and interpretation of the analogous South African offences.

\section{Transvaal}

Part A of the Crimes Ordinance 26 of 1904 created the following forms of statutory housebreaking: ${ }^{8}$ (i) breaking and entering any premises in the night with intent to

6 In terms of Husak's categorisation, these offences are referred to as "simple" inchoate crimes, as opposed to "complex" inchoate crimes, such as attempt, conspiracy or incitement (or "solicitation" in US law) (Husak 1998: 602-604).

7 The text of s 28 of the Larceny Act 1916 (c 50) reads as follows:

28 Being found by night armed or in possession of housebreaking implements -

Every person who shall be found by night (1) armed with any dangerous or offensive weapon or instrument, with intent to break or enter into any building and to commit any felony therein; or

(2) having in his possession without lawful excuse (the proof whereof shall lie on such person) any key, picklock, crow, jack, bit, or other implement of housebreaking; or (3) having his face blackened or disguised with intent to commit any felony; or (4) in any building with intent to commit any felony therein; shall be guilty of a misdemeanor ...

This provision will be compared with the pre-Union provisions in the discussion that follows.

8 Although the words "shall be guilty of an offence" are absent from these provisions, it was pointed out in $R v$ Feelander 1926 TPD 157 at 159 that "it is perfectly clear from the contents of the Ordinance that many of the sections framed in this way were intended not merely to prescribe punishments for common law offences but to create offences ...". The principle of nullum crimen sine lege is thus satisfied. In so far as the breaking and entering offences are concerned, it was held in $R v$ Shlabaan 1910 TS 646, which was followed in $R v$ Marema 1913 TPD 200, that the offences in the Ordinance did not apply to a case where, the premises having been broken into, an offence (usually theft) was actually committed. However, in $R v$ Molete 1913 TPD 572 it was held that the accused was rightly convicted where he had been charged under the Ordinance, despite the 
commit an offence in such premises; ${ }^{9}$ (ii) breaking and entering a dwelling at night with that intent: ${ }^{10}$ (iii) entering dwelling or premises at night with that intent; ${ }^{11}$ (iv) being found by night armed with any dangerous or offensive weapon or instrument with intent to commit any offence mentioned in (i), (ii) or (iii); having in possession without lawful excuse any pick lock, key, crow, jack, jemmy, or other implement of housebreaking; or having the face or person disguised with intent to commit any offence mentioned in (i), (ii) or (iii); ${ }^{12}$ (v) breaking and entering any premises

actual commission of the offence intended, along with the breaking and entering. None of these offences included theft, and where theft followed, a common-law charge ought to follow, although a statutory charge (without the theft) could be brought: $R v$ Molete (ibid).

9 In terms of s 4 of the Ordinance, criminal liability was incurred by "[a]ny person who shall break and enter any premises in the night with intent to commit an offence therein". This provision was repealed by s 1 of the Pre-Union Statute Laws Revision Act 24 of 1979.

10 In terms of $s$ of the Ordinance, criminal liability was incurred by "[a]ny person who shall break and enter any dwelling in the night with intent to commit an offence therein". This provision was repealed by s 1 of the Pre-Union Statute Law Revision Act 43 of 1977. It was held in $R v$ John Cumoya 1905 TS 402 that the indictment in a charge under this section must allege an intent to commit some particular offence. This approach was followed in $R v$ Mdoda (1907) 28 NLR 337.

11 Section 6 of the Ordinance criminalised such unlawful entry: "Any person who shall enter any dwelling or premises in the night with intent to commit an offence therein [commits an offence]." In $R v$ Schonken 1929 AD 36, it was held (at 43-44) that the owner or lawful occupier of the premises or persons lawfully upon the premises could not contravene s 6; the court accepted the argument of defence counsel that serious anomalies would result if the section included owner or lawful occupier: "If an owner goes into the street and then enters his dwelling with the intention of gambling therein he would be hit by sec. 6 , whereas he would not fall under the section if he remained inside and received his fellow gamblers in his house. The same would apply if he entered with intent to commit any other offence." On the facts, however, the accused was not held to be lawfully present on the premises, having been invited to enter for immoral purposes by a female servant without the consent of the owner. Moreover, it was held in $R v$ Depapa 1927 TPD 833 at 835 that once a person is lawfully inside any structure used as a dwelling, he could not be convicted of having entered the dwelling where he moves from one part of the structure to another.

12 Section 7 of the Ordinance provided that an offence was committed by "[a]ny person who shall be found by night: $(a)$ armed with any dangerous or offensive weapon or instrument with intent to commit any offence mentioned in the preceding sections; or $(b)$ having in his possession without lawful excuse (the proof of which excuse shall lie upon such person) any pick lock, key, crow, jack, jemmy, or other implement of housebreaking; or $(c)$ having his face stained or disguised or his person dressed or otherwise disguised with intent to commit any offence mentioned in the preceding sections ...". In terms of s 3 of the General Law Further Amendment Act 93 of 1962, the qualification that the offence be committed by night was removed from the offence contained in $\mathrm{s} 7(b)$. This provision was partly repealed in terms of s 2 the Prohibition of Disguises Act 16 of 1969, which repealed s 7(c), and was further partly repealed in terms of s 1 of the Pre-Union Statute Law Revision Act 43 of 1977, in terms of which s 7(a) was repealed. Section 7(b), the sub-section dealing with housebreaking implements, was repealed in terms of s 84 of the General Law Third Amendment Act 129 of 1993. In terms of an earlier provision, s 1 of Law 2 of 1891 (T), the wearing of any disguise on a public road or in a public place was forbidden - see $S v$ Kola 1966 (4) SA 322 (A). As regards the criminalization of disguise, see Hoctor 2013: 316-321. 
or dwelling in the day-time with that intent; ${ }^{13}$ (vi) entering upon any premises or dwelling or enclosed piece of land attached to or used in connection therewith, and wrongfully and unlawfully refusing to leave: ${ }^{14}$ and (vii) putting anyone in bodily fear by the use of threats or conduct in or upon premises, or its ground, unlawfully broken, entered or remained upon. ${ }^{15}$

A number of essential elements are common to the above offences, and these will be briefly examined below. ${ }^{16}$ To avoid unnecessary duplication, the approach which will be taken is to analyse the elements of the Transvaal provisions in detail, and then to set out the analogous provisions in the other jurisdictions, adverting to relevant case law and developments.

\section{Essential elements of these offences}

\section{Breaking}

The Ordinance defined "break" as "the obtaining of entrance into or exit from any building by means of force, threat, fraud, stealth or trick or by the unfastening or opening of any door or window or by the removal of anything used to cover any opening into or within or from such building." ${ }^{17}$ As Hunt points out, this definition contained a definition of breaking which incorporated the English doctrine of

13 Section 8 of the Ordinance, which provided that "[a]ny person who shall break and enter any premises or dwelling in the day time with intent therein to commit an offence" contravened this section.

14 In terms of $\mathrm{s} 9$ of the Ordinance, an offence is committed by "[a]ny person who shall enter upon any premises or dwelling or enclosed piece of land attached to or used in connection therewith and shall wrongfully and unlawfully remain therein or thereon after request by the occupier or person for the time being in charge thereof to immediately depart therefrom". It was held in $R v$ Flemming 1939 TPD 260 that this provision only applied to premises physically occupied or in charge of some person, and thus there could be no liability where no request to depart had been made by the occupier or person in charge of the premises. This provision was repealed by $\mathrm{s} 3$ of the Trespass Act 6 of 1959.

15 Section 10 of the Ordinance, which stated that "[a]ny person who having unlawfully broken into or entered upon or remained upon any premises or dwelling or enclosed piece of ground attached to or used in connection with such premises [who] shall by any threat or conduct put any one therein or thereon in bodily fear [commits an offence]". In $R v$ Phalane 1953 (4) SA 562 (T), it was held that the words "entered upon" relate only to premises or dwellings and that in so far as enclosed pieces of land are concerned s 10 can only be contravened where they have been unlawfully "remained upon". It was pointed out (per Ramsbottom J) in $R v$ De Beer 1954 (3) SA $82(\mathrm{~T})$ that $\mathrm{s} 10$ contained two distinct offences: putting a person in bodily fear after having entered unlawfully, and putting a person in bodily fear having entered lawfully.

16 I have adopted the useful layout - which does not claim to be exhaustive-utilized in the discussion of these offences by Hunt 1970: 676-682. See, also, De Wet \& Swanepoel 1960: 392-393. Owing to the similarity between the South African statutory housebreaking offences and the analogous English provisions, found in the old Larceny Act of 1916, these will be compared.

17 Section 3. 
"constructive breaking"18 and included the notion of "breaking out". ${ }^{19}$ As a result of the repeal of the definition section of the Ordinance by the Pre-Union Statute Law Revision Act, ${ }^{20}$ the common-law concept of breaking was applied to all cases decided after this Act came into operation. ${ }^{21}$

\section{Entering}

The definition in the Ordinance circumscribed the term "enter" for the purposes of criminal liability as follows: "[T]he insertion of any part of the body of a person or any part of an instrument used by such person within a building." 22 This definition reflects the "well known common law meaning" of the term. ${ }^{23}$ De Villiers $\mathrm{J}$ in $R v$ Brand opined that the word "within" should be read as "into". ${ }^{24}$ It is submitted that this is a correct interpretation, it being essential insofar as the act of "housebreaking" is concerned to link the entry with the breaking. After the passage of the Pre-Union Statute Law Revision Act, the definition of entering contained in the Ordinance was repealed, ${ }^{25}$ and, as was the case with breaking, the common-law definition ${ }^{26}$ was applied in the courts.

\section{Dwelling}

The term "dwelling" 27 was defined in the Ordinance as

a building or structure or any part thereof which is for the time being kept by the owner or occupier thereof for the residence therein of himself, his family or servants or any of them and whether or not such building or structure be from time to time uninhabited.

18 See $R v$ Boyle [1954] 2 All ER 721, where the accused gained entry to the premises by pretending to be a BBC employee on official business. See, further, $R v$ Johnson and Jones (1841) Car \& M 218 , where it was held that there would be an attempt if the accused is admitted by someone who is aware of his intent, and is seeking to trap him. For a discussion of the notion of constructive breaking, see Bhamjee \& Hoctor 2005: 726-733.

19 Hunt 1970: 677. In respect of the common-law crime of housebreaking, the prevailing view appears to be that a breaking out after an unlawful entry does not constitute the crime $-S v$ Maunatlatla 1982 (1) SA 877 (T) at 879. Hunt further points out (1970: 677) that this definition appears to incorporate the former English rule that there is no breaking if the accused further opens an open door or window unless this entails "tampering with some fastening device".

20 In terms of $\mathrm{s} 1$ of Act 43 of 1977.

21 For discussion of "breaking" with regard to the common-law crime of housebreaking, see Hoctor 1998a: 201-229.

22 Section 3. This definition apparently excludes the pre-1968 English rule that the insertion of an instrument is not an entry if it is inserted simply to facilitate the entry itself (Hunt 1970: 677).

$23 R v$ Depapa 1927 TPD 833 at 835.

$24 \quad R v$ Brand $1952(2) \mathrm{SA} 131(\mathrm{~T})$ at 133.

25 In terms of $\mathrm{s} 1$ of Act 43 of 1977.

26 For discussion of the common-law concept of "entering" in the context of the housebreaking crime, see Hoctor 2007: 45-63.

27 Section 3. This definition was repealed by s 1 of the Pre-Union Statute Law Revision Act 43 of 1977. 
The term "part thereof" was held to refer to "a building or structure or a part of the building or structure used as an entity, that is as a dwelling by the complainant and his family." 28

\section{Premises}

The term "premises" ${ }^{29}$ was defined in the Ordinance as

any building or structure or part thereof (not being a dwelling) habitually used as a shop, warehouse, storehouse, bank, office, school or for divine worship or any outbuilding occupied in connection with a dwelling or premises as herein defined.

As was the case in respect of the analogous English provision, ${ }^{30}$ the listing of specific types of "premises" in this definition created problems and anomalous exclusions. ${ }^{31}$ This was evident in the case of $R v$ Simon and Mansin ${ }^{32}$ where a dance hall was excluded from the ambit of the Ordinance. The facile type of reasoning which it was incumbent on the court to employ is evident in a quote from the judgment: "The dance hall was not habitually used as a shop, warehouse, storehouse, bank, office, school or for divine worship. It was used for the purpose of dancing". Despite the fact that the dance hall had offices leading out of it, the court was obliged to hold that it did not fall within the definition of the offence. It was further held that a fowl-run made of iron tubes and wire netting could not be regarded as "premises" ${ }^{33}$ Nor, it was held, could land constitute "premises", even though enclosed on all sides with a sufficient fence, ${ }^{34}$ or a wall, ${ }^{35}$ unless it is established that it is "part" of a "structure" used as a "storehouse". ${ }^{36}$

$28 R v$ Depapa 1927 TPD 833 at 835 . As a result the accused, who was a servant who had lawfully entered the dwelling, could not be convicted of "entering a dwelling" (in contravention of s 6 of the Ordinance) where he had entered another room in the structure.

29 Section 3.

30 The definition employed in s 26 of the Larceny Act 1916 listed the types of premises included in the offence as follows: "[A]ny dwelling-house, or any building within the curtilage thereof and occupied therewith, or any school-house, shop, warehouse, counting-house, office, store, garage, pavilion, factory, or workshop, or any building belonging to His Majesty, or to any government department, or to any municipal or other public authority."

31 See Hunt 1970: 678. In respect of the English provision, Smith \& Hogan 1965: 401 commented that it was unfortunate that this section did not use some comprehensive formula, because although the list given was extensive, it was possible to envisage buildings which did not come within the list (such as unoccupied houses), or only doubtfully came within the list (such as cinemas, dancehalls, unless they contain wares and can be accounted warehouses).

$32 R v$ Simon and Mansin 1936 (1) PH K9 (T).

$33 \quad R v$ Charlie 1916 TPD 367.

$34 \quad R v$ Mohagi 1949 (2) SA 309 (T); $R v$ Ngema 1960 (1) SA 517 (T) at 520; $R v$ Molefi 1960 (3) SA $704(\mathrm{~T})$ at 705.

$35 \quad R v$ Jacobs $1960(4) \mathrm{SA} 683(\mathrm{~T})$ at 684-685.

36 See $R v$ Setlogelo 1934 TPD 73, where the yard in question was both enclosed and locked. In $R v$ Captain (JC 1910,27) (discussed in the Setlogelo case at 75) it was held that a yard enclosed by a fence was neither a dwelling nor a premises. However, the court in Setlogelo (at 75) noted that the pertinent question was as to the nature of the yard, and "the nature of the enclosure and the relation of the enclosure to the building to which it is annexed". 
As with breaking and entry, the definition was statutorily repealed in $1977,{ }^{37}$ and consequently it has been suggested that the term then took on its "ordinary meaning", which may be defined as "a house or building with its grounds or other appurtenances." ${ }^{38}$ It seems that the notion of "premises" for the purposes of the statutory offence would be defined somewhat more broadly than the common-law equivalent. ${ }^{39}$

\section{Night}

Night was defined as "the period between sunset and sunrise" in the Ordinance. ${ }^{40}$ Although the original definition section was repealed by the Pre-Union Statute Law Revision Act, ${ }^{41}$ it seems that this remained the appropriate working definition of "night". ${ }^{42}$ It appears that all the necessary elements were required to take place during the period of "night". ${ }^{43}$ A "breaking" on one night and "entry" on another was sufficient for the purposes of liability, according to some English authority. ${ }^{44}$

37 In terms of s 1 of the Pre-Union Statute Law Revision Act 43 of 1977.

38 Hunt 1990: 719 (by Milton). This definition has been extracted from the Oxford English Dictionary, and was cited by counsel in $R v$ Lushaba $1956(4)$ SA $370(\mathrm{~N})$, where it was accepted by the court.

39 The notion of "premises" in common law is loosely equivalent to the statutory notion of a "dwelling", and can thus be distinguished from the statutory notion of "premises", even as "dwelling" and "premises" were distinct statutory concepts. For discussion of the common-law notion of "premises", see Hoctor 1998a: 127-133.

40 Section 3 of the Ordinance. Concomitantly, "day time" was defined as the period between sunrise and sunset.

41 Act 43 of 1977.

42 Hunt 1990: 719 n 162 states that there is "ample authority" in South African law for this proposition. In the definition section of the Criminal Procedure Act (s 1 of Act 51 of 1977), night is defined as "the space of time between sunset and sunrise". (The means of determining the time of sunset and sunrise has been laid down at s 229 of the Criminal Procedure Act.)

43 For example, the breaking, entering and intent in $\mathrm{s} 4$, and the possession in the case of $\mathrm{s} 7(b): R v$ Davis and Harris (1924) 18 Cr App Rep 157 at 159. Although this was doubted by Turner 1964: 814, this seems to have been the position in former English law (Smith \& Hogan 1965: 397-8).

44 See $R v$ Smith (1820) Russ and Ry 417 (accused broke glass of complainant's side door on the Friday night, with intent to enter at a future time, and actually entered on the Sunday night - the court held this to be burglary, as both breaking and entering took at place at night). Hale 1736: 551 states: "But if they break a hole in the house one night and commit felony, and accordingly they come at another night and commit a felony through the hole they so made the night before, this seems to be burglary, for the breaking and entering were both noctanter, though not the same night; and it shall be supposed they broke and entered the night when they entered, for the breaking makes not the burglary till the entry." Turner 1964: 815 remarks - concerning Hale's statement - as follows: "which reasoning, if applied to a breaking in the daytime, and entering in the night, would seem to refer the whole transaction to the entry, and make such breaking and entering also a burglary". 


\section{With intent to commit an offence}

The word "offence" was held to include "any act punishable by law", and was not limited to offences against the person or property of the owner or occupier. ${ }^{45} \mathrm{It}$ was necessary to prove beyond reasonable doubt that the accused's intention was not benign but was to commit an offence; this is proven by means of a process of inferential reasoning. ${ }^{46}$

\section{Being found}

The word "found" was held not to indicate an element of surprise, in other words, that it was feasible to regard even an accused caught in a prearranged trap as having been "found" ${ }^{47}$ Thus the term "found" was held to mean discovered, perceived ${ }^{48}$ or come across. ${ }^{49}$

\section{In possession}

Hunt argues that the accused had to be found in "direct control" of the implement. ${ }^{50}$ Thus the accused had to be caught in flagrante delicto with the implement in

45 See $R v$ Schonken 1929 AD 36 at 46: "Whether the illicita causa of our common law embraces every unlawful cause or is confined to a criminal intention need not be considered; it certainly includes the intent to commit any crime or offence." Hunt 1970: $678 \mathrm{n} 172$ also points out that it thus included an intent to trespass in contravention of the Trespass Act 6 of 1959, to contravene the Sexual Offences Act 23 of 1957, or to commit an injuria of some other sort ("unlawful entry with an illicit purpose, whether it be to steal, to commit stuprum, adultery or for any other unlawful purpose, is an injuria in the sense of contumelia to the owner or occupier punishable by law": see $R v$ Schonken $1929 \mathrm{AD} 36$ at 45$)$.

46 For example, in $R v$ Bavukukula 1927 TPD 579 at 581, the accused was acquitted because it was not proven that the accused had any intention accompanying his entry of the premises than "merely for the purpose of sleeping there".

47 Beadle $\mathrm{J}$ in the Rhodesian case of $R v$ West and Wild 1953 (2) SA 675 (SR) at 680, commented, with regard to a discussion of a charge of "being found by night without lawful excuse", that this "does not mean that there must be some element of surprise in the detection. I consider, therefore, that the offence can be committed even where the occupier of the premises has full knowledge of the accused's entry". In the earlier Rhodesian case of $R v$ Farukayi 1951 SR 235, the court seems to indicate that prior to a conviction of "being found", the accused's entry upon the premises must be secretive, or at least without the knowledge of the occupier of the premises. The above view, reflected in West and Wild is to be preferred however - see Hunt 1970: 679. As regards the English law position, under the Larceny Act of 1916, see Smith \& Hogan 1965: 402-403.

48 In $R v$ West and Wild 1953 (2) SA 675 (SR) at 680 the court approved the approach taken in $R v$ Bresky 1921 EDL 254 at 258 where the court held that in the particular circumstances of the case "found" meant "to be seen": "The use of the word 'found' amounts, in my opinion, to no more than saying 'seen by some reliable witness in the bar"'. It has been suggested by Williams (1955: 72-3) that to satisfy the "being found" requirement, perception through any of the senses would suffice (as, for instance, where the accused is heard inside a building).

49 Smith \& Hogan 1965: 402, Williams 1955: 72-73.

50 Hunt 1970: 679. Since the new statutory offence relating to possession of housebreaking implements (s 82 of Act 129 of 1993) consists of merely "possessing", rather than "being found in possession" (as per s 7(b) of the Ordinance) it seems that "constructive possession" will suffice (Hoctor 1999a: 232). 
question..$^{51}$ The implement therefore was required to be found either on the accused or to be immediately accessible to the accused, although what this means is somewhat questionable. ${ }^{52}$ Whether one could be "in possession" by means of another is doubtful; it seems that a common purpose between the parties was required..$^{53}$

\section{Housebreaking implements}

As far as the listed housebreaking implements are concerned, "pick lock key" was somewhat confusing. In fact, the Ordinance referred to "pick-lock key", that is, a skeleton key. ${ }^{54}$ The terms "crow", "jack" and "jemmy" all had a specialist meaning in the context of housebreaking and were not problematic. ${ }^{55}$ On the other hand, the courts had had cause to consider the catch-all phrase "or other implement of

$51 \quad R v$ Davis and Harris (1924) 18 Cr App R 157; $R$ v Lester and Byast (1955) 39 Cr App R 157, (1955) Crim LR 648 - in which it was decided that the mere fact that the accused was a passenger in a car containing housebreaking implements is insufficient to prove that he was in possession of them, even if the driver of the car has been held to be in possession of the implements. (The court could, however, convict the accused on these facts if a common purpose to break into houses was proven.) In the commentary on Lester and Byast in the Criminal Law Review (at 648), Stephen's definition of "possession" is cited (contained in his Digest, 9ed at 304): "A movable thing is said to be in the possession of a person when he is so situated with respect to it that he has the power to deal with it as owner to the exclusion of all other persons, and when the circumstances are such that he may be presumed to intend to do so in case of need." See Smith \& Hogan 1965: 403-404, for a discussion of the position in English law under the 1916 Larceny Act. Compare the discussion of the element of "possession" as contemplated in the offence outlined in s 36 of Act 62 of 1955 (discussed in Milton, Cowling \& Hoctor 1988: ch J6).

52 While it is patent that if the implements are found on the person of the accused he will be found "in possession" (as the first accused was in $R v$ Lester and Byast (1955) 39 Cr App R 157), there are a number of possible borderline cases, outlined by Smith \& Hogan 1965: 403-404. Were the implements found at the home of the accused, the authors submit that the guilt of the accused would turn on the nature of his possession: if he was found to leave the house with a jemmy in his pocket, this would suffice for liability, whereas if the implements were simply found somewhere in the house, this would not suffice. Further, if the implements were found in the car of the accused while he was on a housebreaking expedition, this would suffice for liability. A more difficult problem would arise where the accused, fearing capture, threw the implements away. If the implements had been abandoned by accused, it seems that there would have been no liability, whereas if the accused had simply hidden them temporarily, having seen a police officer approach, he would have remained in possession throughout, as the implements "continue to be at hand to him for his purposes". The distinction is rather difficult to draw.

$53 \quad R v$ Thompson (1869) 11 Cox CC 362.

$54 \quad R v$ Dhlamini 1950 (2) SA $175(\mathrm{~T})$, where De Wet AJ (at 176) pointed out that the paragraph is devoid of punctuation, and if one takes into account that in other provincial ordinances (such as that of the Orange Free State) there is a hyphen between "pick" and "lock", and that a lock cannot be regarded as a housebreaking implement, it was clear that the legislative intent was simply to refer to a "pick-lock key". This decision was followed in Sv Mdluli 1978 (3) SA 425 (T). Curiously, both these cases referred to $R v$ Makala 1949 (2) SA 494 (T) as authority on the point (as does Hunt 1970: $679 \mathrm{n}$ 182), although this point does not arise at all in Makala.

55 In $R v$ Makala 1949 (2) SA 494 (T) at 495, Ramsbottom J said of these implements: "Those that are specified are obviously and unambiguously implements of housebreaking". These implements are all species of crowbar, adapted for use by housebreakers. 
housebreaking", ${ }^{56}$ and decided (in the circumstances) that a key, ${ }^{57}$ a hook, ${ }^{58}$ a torch,,${ }^{59}$ a screwdriver ${ }^{60}$ and a chopper and iron spike ${ }^{61}$ (amongst others ${ }^{62}$ ) did not qualify to be included in the category of housebreaking implements. Where the implement was either one of those specifically set out in the provision, or one whose nature unambiguously identifies it as a housebreaking implement, the onus of proving

56 Ramsbottom J in $R v$ Makala 1949 (2) SA 494 (T) at 495 remarked: "[O]ther implements may be implements of housebreaking - whether they are or not depends on the circumstances. But whatever the circumstances may be the article must be such as is capable of use for the purpose of housebreaking."

57 In $R v$ Dhlamini 1950 (2) SA 175 (T) it was held that a bunch of keys could not be considered to be housebreaking implements; in S v Mdluli 1978 (3) SA 425 (T) a door key and two "flat" keys were not considered to be implements - in both cases the circumstantial evidence was held not to indicate such a possibility on the facts. However, Preiss J in Mdluli (at 427b-c) went further in his rejection, raising the spectre of indeterminate liability: "Indien dit aanvaar word dat die sleutels in hierdie saak huisbraakimplemente is, sou dit beteken dat enige persoon wat sleutels in sy besit het waarvan sommige die deure van ander persone kan oopsluit, aan die misdryf skuldig is. Ek is oortuig dat dit nooit die bedoeling van die Wetgewer kon gewees het nie." (See also the cases of $R v$ Jan (1883) 3 EDC 331; $R v$ Tshabalala 1936 TPD 36 at 38, where the same concerns were raised.) The learned judge then asserted that the implements and the circumstances had to be objectively assessed (at 427c). As is apparent in the judgments in both Dhlamini and Mdluli, the possibility of an ordinary key being held to be an implement could not be altogether excluded. See also $R v$ Kahla 1919 SR 29 in this regard.

58 Ramsbottom J in $R v$ Makala 1949 (2) SA 494 (T) rejected the possibility of a hook "in itself and by itself" being an instrument of housebreaking, and pointed out that it could only be used for this purpose if it were attached to a stick (at 496).

59 A torch was held in the circumstances in $R v$ Makala 1949 (2) SA 494 (T) not to be proven to be an implement of housebreaking (at 496). In the Rhodesian case of $R v$ Stephen 1968 (4) SA 267 (R) at 269 , the court held that although a torch may be indicative of a criminal purpose, and is useful to a successful housebreaker in that it helps him to see his way around once inside the house, it cannot be regarded as an implement of housebreaking. Lewis J stated at 269 that "[t]heir [torches and a mask] mere possession, in the circumstances of the present case, is as consistent with an intention to waylay and rob someone on the highway or to steal a car, as with an intention to break into a house".

60 In the case of $R v$ Poza 1954 (4) SA 137 (T), it was held that the mere fact that a screwdriver could be used as a housebreaking implement did not automatically make it a housebreaking implement. Similar reasoning was applied (with similar results) in $R v$ Magadusa 1950 (1) PH K42 (C) and $R v$ Alick 1953 (4) SA 473 (SR). A screwdriver was regarded as a housebreaking implement in appropriate circumstances however - see, eg, the English case of $R v$ Patterson [1962] Crim LR 167.

61 In $R v$ Tshabalala 1936 TPD 36 the court held that it had not been proven that these items, found in the possession of the accused, should be regarded as housebreaking implements.

62 Examples of items found in the possession of suspected offenders which were not considered to be housebreaking implements (in the circumstances) include: (1) a pair of pliers ( $R v$ Tshabalala 1936 TPD 36); (2) socks ( $R$ v Poza 1954 (4) SA 137 (T)) - although the court noted that it is known that socks are used to avoid the creation of fingerprints (at 137); (3) a mask ( $R v$ Stephen 1968 (4) SA 267 (R) - although the court acknowledged that a mask may be useful to someone who has succeeded in gaining unlawful entry to a house at night by helping to conceal his identity (at 269)). 
"lawful excuse" for such possession fell on the accused. ${ }^{63}$ On the other hand, where the article could not intrinsically be identified as an implement of housebreaking, the burden of proof was on the State to prove the intent to use it for the purpose of housebreaking. ${ }^{64}$

It seems that lessons were learned in the drafting of the new offence criminalising the possession of housebreaking (or vehicle-breaking) implements. Instead of an attempt to list notorious housebreaking implements, along with a catch-all category, "any implement or object" which is possessed, in respect of which there is a reasonable suspicion that it may be used for housebreaking, and in terms of which no satisfactory account of such possession can be given, suffices for liability ${ }^{65}$ There is thus a concession that legislators cannot realistically expect to know and specify every one of a myriad of implements, instruments and objects that are utilised in present-day housebreaking.

\section{Lawful excuse}

As to the meaning of "lawful excuse", it seems that a breach of the criminal law should not be contemplated ${ }^{66}$ It is submitted that Smith and Hogan are correct when they suggest that the "possession of housebreaking implements is not unlawful as such, but becomes unlawful where D [the accused] intends to put them to a criminal use" ${ }^{67}$ Thus the accused could avoid liability under the section if he could show that it was not his intention to use the implement at all, or that his intention was merely to display it in his museum, or to only use it in the course of his lawful occupation. ${ }^{68}$

63 Hunt 1970: 679; $R v$ Tshabalala 1936 TPD 36 at 38, deriving support from the English case of $R$ $v$ Oldham (1852) $21 \mathrm{LJ}$ (NS) MC 134 (cited at 39). The Tshabalala decision was followed in $R v$ Mathlakoe 1939 TPD 352.

$64 R v$ Tshabalala 1936 TPD 36 at 38 . The English courts adopted an approach which was much more onerous for the accused, as outlined in $R v$ Patterson [1962] Crim LR 167 at 168: "The proper approach was this: in the first instance the prosecution had to prove that the prisoner was found in possession by night of either an implement which could properly be described as one of those named in the section [s 28(2) of the Larceny Act 1916] or of an implement capable in fact of being used as a housebreaking implement from its common though not exclusive use for that purpose, or from the particular circumstances of the case in question. Once possession of such an implement had been shown, the burden shifted on to the prisoner to prove on the balance of probabilities that there was lawful excuse for his possession of the implement at the time and place in question." See Smith \& Hogan 1965: 406.

65 Section 82 of the General Law Amendment Act 129 of 1993.

66 Smith \& Hogan 1965: 406. The accused would not be held responsible in law therefore if he intended to break into and enter his own house or room, having misplaced his key. Further, it seems that the intent to break and enter for an immoral purpose would not suffice.

67 Smith \& Hogan 1965: 406. The authors suggest that it may be enough if the accused is found in possession of housebreaking implements, which he intends to use on some future occasion, and not on the night when he is found.

68 Hunt 1970: 680. Once possession of such an implement had been shown, and a prima facie case had thus been established, the onus shifted to the accused to prove a lawful excuse for his possession, on a balance of probabilities. 
In contrast to the Transvaal ordinance, where the phrase "without lawful excuse" appeared in the other provincial housebreaking statutes ${ }^{69}$ in the context of a form of trespass, it has been argued that the accused does not necessarily escape by showing absence of intent to commit a crime..$^{70}$ Hunt opines that the accused probably could only escape if he could show that he "was engaged in innocent pursuits and having no reason to anticipate objection on the part of the owner or occupier". ${ }^{71}$

\section{Natal}

The statutory offences relating to housebreaking and intrusion were contained in section 6(2) of the Criminal Law Amendment Act of 1910. ${ }^{72}$ These offences may be listed as follows: (a) Housebreaking with intent to commit some crime, whether the particular crime be known or not; ${ }^{73}$ (b) Entering a house or premises with intent to commit some crime, whether the particular crime be known or not; ${ }^{74}$ (c) Being in possession without lawful excuse (the proof of which excuse shall be upon the accused), and between the hours of sunset and sunrise, of a picklock, key, crow,

69 Section 6(2)(d) of Act 10 of $1910(\mathrm{~N})$; s 8(3) of Act 27 of $1882(\mathrm{C})$; s 129(3) of Act 24 of $1886(\mathrm{C})$; s 26(3) of Ordinance 21 of $1902(\mathrm{O})$.

70 This was decided in $R v$ Botha 1919 EDL 144 and $R v$ Matsinya 1937 EDL 358 - thus it seems that the accused would be guilty if he had reason to anticipate that his presence would be objected to. The court in $R v$ Joseph Andrews (1883) 3 EDC 221 and $R v$ Booyse (1907) 27 EDC 275 required proof of a criminal intent, presumably to commit some offence other than the trespass itself. In $R$ $v$ Renton 1937 EDL 14, as regards the presence in premises of domestic servants "without lawful excuse", the court adopted the reasoning applied in the Rhodesian case of $R v$ Tokoli 1918 SR 169.

71 Per Van den Heever J in $R v$ Jacob Jakwane 1944 OPD 139 at 143. See, further, the Rhodesian cases of $R v$ Ulexi 1916 SR 33 and $R v$ Tokoli 1918 SR 169.

72 It was held in $R v$ Mtetwa 1930 NPD 285 that this subsection did not merely confer jurisdiction on the courts, but created statutory offences.

73 Section 6(2)(a). This provision overturned the precedent established in $R v$ Mdoda (1907) 28 NLR 337 , where it was held (at 340) that a charge of "wrongfully entering a bedroom with unlawful intent, to wit, with intent to commit some crime to the prosecutor unknown" was an embarrassment to all the parties in the court proceedings. This charge was subsequently enabled at a national level by s 132(11) of the Criminal Procedure Act 31 of 1917, and it was repeated in the succeeding Criminal Procedure Acts 56 of 1955 (s 320(11)) and 51 of 1977 (s 95(12)). For further discussion of the crime of housebreaking with the intent to commit a crime to the prosecutor unknown, see Hoctor 1996: 160-167. See $R v$ Ntuli 1957 (4) SA 42 (N) at 46-47, where the accused's intention was not established, in the view of the court. This subsection was repealed by $\mathrm{s} 1$ of the Pre-Union Statute Law Revision Act 43 of 1977.

74 In $R v$ Dunlop $1954(1)$ PH H13 (N), the court held that a charge under s 6(2)(b) cannot be combined with a charge of theft, as is possible with regard to the common-law crime of housebreaking with intent, because this is not sanctioned under the statute. Thus in circumstances which admit of a possible theft conviction as well as a conviction under s $6(2)(b)$, it is open to the court to convict either of entering premises with intent to steal or of theft. The position is apparently the same with regard to s 6 of the Transvaal ordinance (Part A of the Crimes Ordinance of 1904), according to Hunt 1970: 680 n 193). 
or other implement of housebreaking: ${ }^{75}$ (d) Being without lawful excuse (the proof of which excuse shall be upon the accused), and between the hours of sunset and sunrise, in or upon any dwelling house, warehouse, coach house, stable, cellar, or outhouse, or in any enclosed yard, garden or area: ${ }^{76}$ and (e) (In the case of a male person) being found dressed as a woman in circumstances indicating a probable intention of availing himself of such disguise in order to commit a crime, whether such intended crime be known or not. ${ }^{77}$

\section{Essential elements ${ }^{78}$}

Although there are no definitions contained in Act 10 of $1910(\mathrm{~N})$, the courts have had occasion to discuss the ambit of certain terms: (i) "housebreaking" - In $S v$ $X u l u,{ }^{79}$ the court held that where the Legislature referred to "housebreaking" in section 6 of Act 10 of $1910(\mathrm{~N})$, it intended that the term should have the same meaning as it had at common law, namely that of "breaking into premises". Thus, with regard to a charge under section $6(2)(a)$, it was insufficient merely to allege and prove a breaking in the sense of damage to and displacement of some portion of the premises; the averment and proof of an entry into the premises was required..$^{80}$

75 See the discussion re "lawful excuse" and the question of onus supra (at 21 10). Hunt 1970: $680 \mathrm{n} 195$ notes that there are important distinctions to be observed between s 6(2)(c) and the corresponding s $7(b)$ of the Transvaal ordinance. First, the crime is "being in possession", not "being found in possession" - this seems to indicate that the accused need not be caught redhanded (ie in direct control) with the implement. To use the terminology favoured by English writers such as Smith \& Hogan, the accused's possession can be "constructive", it need not be "actual". Secondly, there is a comma between "picklock" and "key", raising the possibility of a differing approach in Natal to the approach adopted in the Transvaal, whereby only skeleton keys were held to be unambiguous implements of housebreaking (see 219 supra). It is Hunt's submission however that because the contrary interpretation would lead to absurdity, "key" must be interpreted eiusdem generis to mean "key such as housebreakers normally use", ie "skeleton key". Thirdly, the terms "jack" and "jemmy" have been omitted in the Natal statute. Hunt suggests that this is because they were regarded as unambiguously "implements of housebreaking".

76 In order to obtain a conviction under this subsection (s 6(2)(d)), it was not necessary to prove that the accused was there with intent to commit an offence ( $R v$ Sitole $1957(4)$ SA $168(\mathrm{~N}))$, it was sufficient if he was there without lawful excuse.

77 In both $R v$ Mkize 1940 NPD 374 and $R v$ Zulu 1947 (1) SA $241(\mathrm{~N})$ it was held that there could be no conviction of the accused simply on the basis of being dressed as a woman, but that it was essential to adduce evidence indicating the probable existence of an intention to commit a crime while so disguised. This subsection (s 6(2)(e)) was repealed by s 2 of the Prohibition of Disguises Act 16 of 1969, which created a national offence of "being in disguise in suspicious circumstances" (s 1). For discussion of criminality and disguises, see Hoctor 2013: 316-321.

78 See the above discussion of the essential elements of the offences under the Transvaal ordinance supra.

79 Sv Xulu 1961 (4) SA $72(\mathrm{~N})$ per Wessels J.

$80 \quad$ Sv Xulu 1961 (4) SA $72(\mathrm{~N})$ at 74. 
(ii) "premises" - This term, in the context of section 6(2)(b), has been held to mean "a house or building with its grounds or other appurtenances" ${ }^{81}$ It therefore includes breaking into the yard of a house, ${ }^{82}$ and into the cabin of a ship, ${ }^{83}$ but not on to a ship "qua ship and the open deck of a ship".

\section{Cape, Transkei, Orange Free State}

The provisions of section 8 of the Police Offences Act 27 of 1882 (C), section 129 of the Transkeian Penal Code of 1886 (Act 24 of 1886 (C)) and section 26 of the Police Offences Ordinance 21 of 1902 (O) were virtually identical, establishing the following statutory offences: (a) Having custody or possession without lawful excuse (the proof of which is on the accused) of "any pick-lock, key, crow or other implement of housebreaking"; 84 (b) Being found by night with blackened face or wearing felt or other slippers, or being dressed or otherwise disguised with criminal intent ${ }^{85}$ (c) Being found by night without lawful excuse (proof of which is on the accused) "in or upon any dwelling-house, warehouse, coach-house, stable, cellar, or outhouse, or in any enclosed yard, garden, or area, or in or on board any ship or other

81 This is the meaning of "premises" contained in the Oxford Dictionary, cited in $R v$ Lushaba 1956 (4) SA 370 (N) at 370-371, and followed in Rv Smith 1959 (4) SA 524 (N) at 526. As Hunt

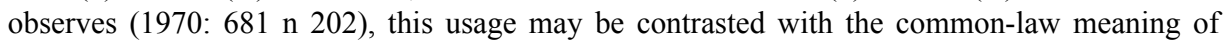
"premises", which may apply to s 6(2)(a) in accordance with $S v$ Xulu 1961 (4) SA $72(\mathrm{~N})$.

$82 R$ v Lushaba $1956(4)$ SA $370(\mathrm{~N})$; Hunt 1970: 681.

$83 R v$ Abraham $1953(1)$ PH H50 (N).

84 Section 8(1)(C), s 129(1) (Transkei), s 26(1)(O). Hunt notes 1970: $682 \mathrm{n} 208$ ) that in the Orange Free State provision there was no comma between "pick-lock" and "key", and that in $R v$ Dhlamini 1950 (2) SA 175 (T) at 176 it was stated obiter of this provision that the words "pick-lock" and "key" must be read together to mean "skeleton key". It seems that the position in the Cape and Transkei was similar to that under the Natal ordinance, that is, to avoid problematic and contrary distinctions, "key" was required to be interpreted to mean "skeleton key". It was held in $R v$ Jan (1883) 3 EDC 331 that mere possession of door keys does not amount to the offence. Similarly, in the Orange Free State case of $R v$ Nqutsbenar 1941 OPD 246, it was held that possession of a bunch of keys could not give rise to liability without proof of intent to use for the purposes of housebreaking. It seems, too, that the notion of "possession" (as in the Natal ordinance) had a wider ambit of application, that is, that "constructive" possession would suffice for liability. (See supra discussion of the differences between the position in Natal and Transvaal at $\mathrm{n}$ 75). In $S v$ Smith 1965 (4) SA 166 (C), it was held that where both the physical and mental elements constituting custody and possession have been established, and where the enactment consists of an unqualified prohibition and does not in express terms require mens rea to be established (as in the offence contained in s 8(1)), the onus of negativing mens rea rested on the accused. The State would however have to prove that the accused had actual knowledge of the implements if he were to be arrested and charged along with another party who was carrying the implements in question ( $R v$ Savage (1903) 13 CTR 459).

85 This provision was repealed in the Cape, Transkei and the Orange Free State by the Pre-Union Statute Law Revision Act (43 of 1977). For further discussion, see Hoctor 2013: 316-321. 
vessel when lying or being in any port, harbour, or place"; $; 6$ and (d) Being found by night armed with a criminal intent or, being thereto required, being unable to assign a satisfactory reason for being so armed. ${ }^{87}$

A further type of statutory housebreaking was created for the Transkei by section 215 of the Transkeian Penal Code: breaking and entering a building with intent to commit any offence thereon, or breaking out of such building either after committing or after having entered to commit such offence therein. The incorporation of a person breaking out of the building within the ambit of the offence clearly extends the scope of housebreaking liability beyond the reach of the common-law crime.

86 In $R v$ Botha 1919 EDL 144 at 148 it was held that the object of this provision was to protect "the enclosed portions of private and occupied property against encroachments by night". Note regarding this (collective) provision that in terms of s 129(3) (Transkei) liability ensued if the accused is found "loitering in the neighbourhood of" such premises or enclosed area "or in any kraal". In $R v$ Nambu 1917 EDL 126 it was held that this offence was not committed where the charge was that the accused was "in the neighbourhood" of a kraal. The Orange Free State provision (s 26(3)) omitted any mention of ships (understandably). See s 8(3)(C) for the Cape version of the offence. In $R v$ Swiegers 1929 GWLD 52 at 55 it was held that the expression "found by night" implies that the offender had come there "secretly or without the knowledge of the occupants of the house", and thus did not apply where, as in the case at hand, the accused knocked at the door and thereafter entered. In an earlier case, $R v$ Harris 1931 EDL 58 at 61, Nathan AJ opined as follows as regards the use of the word "found" in a charge: "All that it means is that the person was seen to be there. It does not appear to be necessary that the accused should be suddenly discovered or encountered or caught in the place in question." The period of "night" was not defined in the statutes, and in the case of $R v$ Shagala 1920 CPD 266, Gardiner J adopted the test favoured in English law, that the central enquiry was whether "the countenance of a person might be discerned". However, in $R v$ Kolela 1922 EDL 125, the court held (per Graham JP) that the objectivized test "the period between sunset and sunrise" was to be preferred, to avoid "grave difficulties in practice": "In these latitudes our twilight is of brief duration. Darkness frequently follows sunset without any interval. Moreover, much would depend on the nature of the weather, whether the sky was clear or clouded, and the definition would lead to a difficult and sometimes prolonged investigation into the meteorological conditions of the locality where the offence was alleged to have been committed (at 130)." The court in Kolela (per Graham JP) further distinguished the case of Shagala in observing that "in the case referred to [Shagala] there was evidence that it was 'quite light' at the time the accused were apprehended, whereas in the case under consideration the witnesses speak to the offence being committed 'at night' ..." (at 128). The Kolela view, formally introduced into South African law by way of the Criminal Procedure Act as early as 1917 (Act 31 of 1917), has been accepted as the correct view. The argument which was rejected in Kolela, then favoured in English law, held that "night" meant one hour after sunset and one hour before sunrise, the rationale apparently being "to prevent darkness being used as a cover for the preparation for crime" (at 126). As regards the notion of "an enclosed yard, garden or area", it was held in $R v$ Jallie 1930 CPD 154 that a lane enclosed on three sides but with the fourth open is not an enclosed area. In $R v$ Pieterse 1911 OPD 3 it was held that where no provision has been made for closing the openings in the surrounding wall, a yard cannot be regarded as enclosed.

87 De Villiers J in $R v$ Cuttings 1946 CPD 187 observed that this section contained two nocturnal offences; being found carrying a weapon and with a criminal intent (which requires proof of intent), and being found carrying a weapon in the absence of a good reason (at 188). This section was repealed by s 1 of the Pre-Union Statute Law Revision Act 43 of 1977. 


\section{Conclusion}

It is evident that the pre-Union statutes regulating housebreaking and intrusion provided a very useful basis for allowing law enforcement authorities to intervene at an even earlier stage than the common-law housebreaking crime allows, in order to deal with threatening conduct. However, these provisions have been replaced by more modern statutory provisions, which in combination with the common-law housebreaking crime are able to efficiently deal with the challenges which the preUnion statutes sought to combat.

Thus, the "breaking and entering" 88 offences are adequately subsumed in the protection offered by the common-law crime; the "unlawful entry" and "unlawful remaining" offences ${ }^{89}$ have been replaced by the statutory offence of trespass ${ }^{90}$; the "possession of housebreaking implements" offences ${ }^{11}$ have been replaced by the statutory offence of "failure to give a satisfactory account of possession of an implement or object"; $; 2$ the offence of "putting anyone in bodily fear" 93 is no longer required in the light of the offence of intimidation; $; 4$ and the offences criminalising being in disguise in suspicious circumstances ${ }^{95}$ have been replaced by a single national offence. ${ }^{96}$ The usefulness of the pre-Union offences were also further undermined by developments in respect of the common-law housebreaking crime. The acceptance that attempted housebreaking to commit a crime is a valid charge and basis for conviction ${ }^{97}$ allowed for some of the acts targeted by the offences to be dealt with as an attempt to commit the common-law crime. ${ }^{98}$ The extension of

88 Section 4, s 5 and s 8 of the Crimes Ordinance 26 of $1904(\mathrm{~T})$; s 6(2)(a) of the Criminal Law Amendment Act 1910 (N); s 215 of the Transkei Penal Code Act 24 of 1886 (C).

89 Section 6 and s 9 of the Crimes Ordinance 26 of $1904(\mathrm{~T})$; s 6(2)(b) and s 6(2) $(d)$ of the Criminal Law Amendment Act 1910 (N); s 8(3) of the Police Offences Act 27 of 1882 (C); s 129(3) of the Transkei Penal Code Act 24 of 1886 (C); s 26(3) of the Police Offences Ordinance 21 of 1902 (O).

90 Section 1 of the Trespass Act 6 of 1959.

91 Section 7(b) of the Crimes Ordinance 26 of $1904(\mathrm{~T})$; s 6(2)(c) of the Criminal Law Amendment Act $1910(\mathrm{~N})$; s 8(1) of the Police Offences Act 27 of $1882(\mathrm{C})$; s 129(1) of the Transkei Penal Code Act 24 of 1886 (C); s 26(1) of the Police Offences Ordinance 21 of 1902 (O).

92 Section 82 of the General Law Third Amendment Act 129 of 1993.

93 Section 10 of the Crimes Ordinance 26 of 1904 (T).

94 Section 1(1) of the Intimidation Act 72 of 1982.

95 Section 7(c) of the Crimes Ordinance 26 of $1904(\mathrm{~T})$; s 6(2)(e) of the Criminal Law Amendment Act $1910(\mathrm{~N})$; s 8(2) of the Police Offences Act 27 of 1882 (C); s 129(2) of the Transkei Penal Code Act 24 of 1886 (C); s 26(2) of the Police Offences Ordinance 21 of 1902 (O).

96 Section 1 of the Prohibition of Disguises Act 16 of 1969.

97 On this development, see Hoctor 2007: 600-606.

98 Such acts could include the offences which targeted persons being found by night armed with a dangerous weapon or instrument with a criminal intent (specified as relating to breaking and entry, or entry, in the Transvaal legislation): s 7(a) of the Crimes Ordinance 26 of 1904 (T); s 8(4) of the Police Offences Act 27 of 1882 (C); s 129(4) of the Transkei Penal Code Act 24 of 1886 (C); s 26(4) of the Police Offences Ordinance 21 of $1902(\mathrm{O})$. 
housebreaking liability to include housebreaking with the intent to commit a crime to the prosecutor unknown ${ }^{99}$ has done away with the need for an offence to deal with the intruder who is on the premises, but who has not yet revealed which crime he is contemplating. The use of a reverse onus in some of the pre-Union offences ${ }^{100}$ would also not be acceptable today, in the light of the constitutionally protected presumption of innocence. ${ }^{101}$

Nevertheless, the pre-Union offences, and the case law flowing from the application of these provisions, still provide a useful reference point for the regulation of housebreaking and intrusion, and provide an interesting perspective on the legal development in this particular area of the criminal law, relating to the basic need to be secure in one's own dwelling or premises.

\section{BIBLIOGRAPHY}

Anders, PC \& Ellson, SE (1915) The Criminal Law of South Africa (Johannesburg)

Bhamjee, S \& Hoctor, SV (2005) “Constructive breaking - A constructive part of the housebreaking crime?" Obiter 26(3): 726-733

Burchell, JM (2016) Principles of Criminal Law 5ed (Cape Town)

De Wet, JC \& Swanepoel, HL (1960) Strafreg 2ed (Durban)

De Wet, JC (1985) De Wet \& Swanepoel Strafreg 4ed (Durban)

Gie, CJC (1941) ' $n$ Kritiek op die Grondslae van die Strafreg in Suid-Afrika (PhD thesis, University of Pretoria, 1941)

Hale, M (1736) The History of the Pleas of the Crown vol 1 (London)

Hoctor, SV (1996) "Some constitutional and evidential aspects of the offence of housebreaking with intent to commit a crime" Obiter 17(1): 160-167

Hoctor, SV (1998a) “The 'premises' element of the crime of housebreaking with the intent to commit a crime" Obiter 19(1): 127-133

Hoctor, SV (1998b) "The 'breaking' requirement in the crime of housebreaking with intent" Obiter 19(2): 201-229

Hoctor, SV (1999a) "The historical antecedents of the housebreaking crime" Fundamina 5: 97103

99 See discussion at n 73 supra.

100 See, eg, s 7(b) of the Crimes Ordinance 26 of $1904(\mathrm{~T})$; s 6(2)(c) and s 6(2)(d) of the Criminal Law Amendment Act $1910(\mathrm{~N})$; s 8(1) and s 8(3) of the Police Offences Act 27 of 1882 (C); s 129(1); s 129(3) of the Transkei Penal Code Act 24 of 1886 (C); s 26(1) and s 26(3) of the Police Offences Ordinance 21 of $1902(\mathrm{O})$.

101 Section 35(3)(h) of the Constitution of the Republic of South Africa, 1996. The approach of the Constitutional Court is reflected in the statement by Kentridge AJ in the case of $S v$ Zuma 1995 (1) SACR 568 (CC) at 583h: "The real concern is not whether the accused must disprove an element or prove an excuse, but that an accused may be convicted while a reasonable doubt exists. Where that possibility exists, there is a breach of the presumption of innocence." 
Hoctor, SV (1999b) "Statutory housebreaking and vehiclebreaking” Obiter 20(2): 225-239

Hoctor, SV (2007) "The entry requirement in the crime of housebreaking" in Hoctor, SV \& Schwikkard, PJ The Exemplary Scholar: Essays in Honour of John Milton (Cape Town): 45-63

Hoctor, SV (2007) “Attempted housebreaking with intent to commit a crime" Obiter 28(3): 600606.

Hoctor, SV (2013) "The offence of being found in disguise in suspicious circumstances" (2013) Obiter 34(2): 316-321

Hunt, PMA (1970) South African Criminal Law and Procedure: Common-law Crimes vol 2, 1ed (Cape Town)

Hunt, PMA (1990) South African Criminal Law and Procedure: Common-law Crimes vol 2, 2ed (Cape Town (revised reprint) by Milton, JRL)

Husak, D (1998) "Reasonable risk creation and overinclusive legislation" Buffalo Criminal LR 1: $599-626$

Matthaeus, A (1987) De Criminibus ad lib XLVII et XLVIII Dig. Commentarius (trl by

Hewett, ML \& Stoop, BC) (Cape Town)

Milton, JRL, Cowling, MG \& Hoctor, SV (1988- , looseleaf) South African Criminal Law and Procedure: Statutory Offences vol 3, 2ed (Cape Town)

Milton, JRL (1996) South African Criminal Law and Procedure: Common-law Crimes vol 2, 3ed (Cape Town)

Pittman, W (1950) Criminal Law in South Africa 3ed (Johannesburg)

Smith, JC \& Hogan, B (1965) Criminal Law 1ed (London)

Snyman, CR (2014) Criminal Law 6ed (Durban)

Turner, JWC (1964) Russell on Crime vol 2, 12 ed (London)

Van der Linden, J (1806) Regtsgeleerd Practicaal en Koopmans Handboek (Amsterdam)

Van Leeuwen, S (1720) Het Rooms-Hollands-Regt (Amsterdam)

Voet, J (1955) Commentarius ad Pandectas (The Selective Voet, Being the Commentary on the Pandects) (trl by Gane, P) (Durban)

\section{Cases}

\section{English}

$R v$ Boyle [1954] 2 All ER 721

$R v$ Davis and Harris (1924) 18 Cr App Rep 157

$R v$ Johnson and Jones (1841) Car \& M 218

$R v$ Lester and Byast (1955) 39 Cr App R 157

$R v$ Oldham (1852) $21 \mathrm{LJ}$ (NS) MC 134

$R v$ Patterson [1962] Crim LR 167

$R v$ Smith (1820) Russ and Ry 417

$R v$ Thompson (1869) 11 Cox CC 362 


\section{South Africa}

$R v$ Abraham 1953 (1) PH H50 (N)

$R v$ Alick 1953 (4) SA 473 (SR)

$R v$ Joseph Andrews (1883) 3 EDC 221

$R v$ Bavukukula 1927 TPD 579

$R v$ Booyse (1907) 27 EDC 275

$R v$ Botha 1919 EDL 144

$R v$ Brand 1952 (2) SA 131 (T)

$R v$ Bresky 1921 EDL 254

$R v$ Charlie 1916 TPD 367

$R v$ John Cumoya 1905 TS 402

$R v$ Cuttings 1946 CPD 187

$R v$ Dhlamini 1950 (2) SA 175 (T)

$R v$ De Beer and Another 1954 (3) SA 82 (T)

$R v$ Depapa 1927 TPD 833

$R v$ Dunlop 1954 (1) PH H13 (N)

$R v$ Farukayi 1951 SR 235

$R v$ Feelander 1926 TPD 157

$R v$ Flemming 1939 TPD 260

$R v$ Fourie/Louw 1907 ORC 58

$R v$ Harris 1931 EDL 58

$R$ v Jacobs 1960 (4) SA 683 (T)

$R v$ Jacob Jakwane 1944 OPD 139

$R v$ Jallie 1930 CPD 154

$R v$ Jan (1883) 3 EDC 331

$R v$ Kahla 1919 SR 29

$R v$ Kolela 1922 EDL 125

$R v$ Lushaba 1956 (4) SA $370(\mathrm{~N})$

$R v$ Magadusa 1950 (1) PH K42 (C)

$R v$ Makala 1949 (2) SA 494 (T)

$R v$ Marema 1913 TPD 200

$R v$ Mathlakoe 1939 TPD 352

$R v$ Matsinya 1937 EDL 358

$R v$ Mdoda (1907) 28 NLR 337

$R v$ Mkize 1940 NPD 374

$R v$ Mohagi 1949 (2) SA 309 (T)

$R v$ Molefi 1960 (3) SA 704 (T) 
$R v$ Molete 1913 TPD 572

$R$ v Mososa 1931 CPD 348

$R v$ Mtetwa 1930 NPD 285

$R v$ Nambu 1917 EDL 126

$R v$ Ngema 1960 (1) SA 517 (T)

$R v$ Nqutsbenar 1941 OPD 246

$R v$ Ntuli 1957 (4) SA $42(\mathrm{~N})$

$R v$ Phalane 1953 (4) SA $562(\mathrm{~T})$

$R v$ Pieterse 1911 OPD 3

$R v$ Poza 1954 (4) SA 137 (T)

$R v$ Renton 1937 EDL 14

$R v$ Savage (1903) 13 CTR 459

$R v$ Schonken 1929 AD 36

$R v$ Setlogelo 1934 TPD 73

$R v$ Shagala 1920 CPD 266

$R v$ Shlabaan 1910 TS 646

$R v$ Simon and Mansin 1936 (1) PH K9 (T)

$R v$ Sitole 1957 (4) SA 168 (N)

$R v$ Smith 1959 (4) SA 524 (N)

$R v$ Stephen 1968 (4) SA 267 (R)

$R v$ Swiegers 1929 GWLD 52

$R v$ Thompson 1905 ORC 127

$R v$ Tokoli 1918 SR 169

$R v$ Tshabalala 1936 TPD 36

$R v$ Ulexi 1916 SR 33

$R v$ West and Wild 1953 (2) SA 675 (SR)

$R v$ Zulu 1947 (1) SA 241 (N)

Sv Jecha 1984 (1) SA 215 (Z)

$S v$ Kola 1966 (4) SA 322 (A)

Sv Maunatlala 1982 (1) SA 877 (T)

Sv Mdluli 1978 (3) SA 425 (T)

$S v$ Smith 1965 (4) SA 166 (C)

$S v$ Xulu 1961 (4) SA $72(\mathrm{~N})$

Sv Zuma 1995 (1) SACR 568 (CC)

\section{Legislation}

Larceny Act 1861 (24 \& 25 Vict Cap 96)

Police Offences Act 27 of 1882 (C)

Native Territories Penal Code Act 24 of 1886 (C) 
Masks and Disguises Law 2 of 1891 (T)

Police Offences Ordinance 21 of 1902 (O)

Crimes Ordinance 26 of 1904 (T)

Criminal Law Amendment Act of 1910 (N)

Larceny Act 1916 (c 50)

Criminal Procedure Act 31 of 1917

Criminal Procedure Act 56 of 1955

Trespass Act 6 of 1959

General Law Further Amendment Act 93 of 1962

Prohibition of Disguises Act 16 of 1969

Pre-Union Statute Law Revision Act 43 of 1977

Criminal Procedure Act 51 of 1977

Pre-Union Statute Laws Revision Act 24 of 1979

General Law Third Amendment Act 129 of 1993

Constitution of the Republic of South Africa, 1996 